Brit. F. industr. Med., 1966, 23, 282

\title{
Studies in Lead Poisoning \\ Oral Therapy with Penicillamine: Relationship between Lead in Blood and other Laboratory Tests
}

\author{
STIG SELANDER, KIM CRAMÉR, AND LEIF HALLBERG \\ From Medical Services I and II, Sahlgrenska Sjukhuset, \\ University of Göteborg, Göteborg, Sweden
}

Fifteen workers with lead poisoning of varying degrees were treated with penicillamine given by mouth. The effect on symptoms and pathological laboratory values was satisfactory, side effects were generally mild and the drug is considered to be a good alternative to Ca-EDTA, which must be given intravenously. Previous studies on the reliability of different laboratory tests in evaluating the degree of lead poisoning and the effect of the therapy were extended with special respect to the lead levels in blood.

The correlations between lead in blood and lead in urine, coproporphyrins in urine and lead excreted during treatment were of the same order as those found between delta-aminolaevulic acid (ALA) in urine and the same parameters. As could be expected, the correlation between the initial values of lead in blood and ALA in urine was very strong $(\mathrm{P}<0 \cdot 00 \mathrm{I})$. It also persisted during treatment.

It is concluded that penicillamine is efficient and useful in the treatment of lead poisoning. Determinations of lead in blood and ALA in urine are equivalent as expressions of lead poisoning, provided that the lead level in blood is not temporarily raised because of an acute exposure.

Calcium Versenate (Ca-EDTA) is the most commonly used agent in the treatment of lead poisoning. The main disadvantage of this substance is that it has to be given intravenously to obtain an adequate effect, which usually makes it necessary to admit the patient to hospital. Another disadvantage of the Ca-EDTA therapy is its inherent risk of inducing severe renal damage (Foreman, Finnegan, and Lushbaugh, 1956; Moeschlin, 1957; Vogt and Cottier, 1957). The drug has thus been reserved for more severe cases and has not been given to the majority of patients with a minor degree of lead poisoning. In these patients, the only measure has been a temporary withdrawal from contact with lead, which would subsequently tend to increase the lead stores in the body. It would thus be of great practical importance to find an effective agent which could be administered orally and which had no or minor side effects. Oral therapy with Ca-EDTA has not been satisfactory (Rieders and Brieger, I955; Shiels, Thomas, and Kearley, I956) because of the poor absorption of the drug in the gastro-intestinal tract (Foreman, 1960). Another agent, d-penicillamine (PCA)-introduced by Walshe in 1956 as a

Received for publication February I8, 1966 chelating agent for cupric ions in patients with Wilson's disease-has been found to increase the urinary lead excretion when given orally to patients with lead poisoning (Boulding and Baker, 1957; Harris, 1958; Ohlsson, 1962; Perol, Graveleau, Potter, and Morin, 1962). The number of subjects studied was small, however, and long-term therapy was given in only a few cases (Goldberg, Smith, and Lochhead, 1963; Moncrieff, Koumides, Clayton, Patrick, Renwick, and Roberts, 1964).

The purpose of the present work was to make a more detailed study of the effectiveness of oral PCA therapy of lead poisoning, including studies of various dosage schedules and the occurrence of side effects. Moreover, we wanted to extend previous studies (Cramér, and Selander, 1965) on the reliability of different laboratory tests with respect to the evaluation of the degree of lead poisoning and the effect of the therapy.

\section{Material}

PCA was given to 15 patients with varying degrees of lead poisoning. (Some authors make a distinction between lead poisoning and lead affection. We use the term 'lead poisoning' for all degrees of lead influence which give rise to pathological changes in the human 
organism.) Thirteen patients were employed in shipbreaking yards, and two (XI and XIII) were working in a storage battery factory. Usually lead poisoning was discovered in connexion with prescribed medical examinations. Clinical and laboratory data on the patients at the start of the therapy are given in Table I. It can always be a matter of discussion if all the symptoms are due to lead poisoning. They have, however, appeared during exposure to lead and they are described in connexion with lead poisoning by several authors (Dagg, Goldberg, Lochhead and Smith, I965; Johnstone, 1964; Zavon, 1964). Table I shows that there was a great variation in the clinical picture and that the laboratory tests covered a wide range from clearly pathological values to border-line values. The interval between the last exposure to lead and the beginning of the therapy varied from one to five weeks. Thus, the data reported in Table I probably reflect a long-term lead affliction rather than an acute exposure.

The subjects were healthy except for the symptoms and findings reported. However, the intake of alcoholic beverages was considerable in several of the subjects.
In addition to the values given in Table $I$, it should be mentioned that granulocytopenia with a polynuclear count between 1,900 and 1,250 cells per mm. ${ }^{3}$ was found in five subjects (II, III, V, VI, and XV). Sternal puncture was performed in four patients (I, IV, VIII, and XII) and revealed a toxic influence on the myelopoietic system. The changes were moderate and consisted of toxic granulation, vacuolization of the cytoplasm, clumsiness of the metamyelocytes and the neutrofile band forms, plasmo-cellular reaction, and the presence of Döhle bodies. *

In seven subjects (III, IV, VI, VII, IX, XIV, and XV), laboratory values indicating liver damage were found, i.e., slight increases in serum glutamic oxaloacetic and pyruvic transaminases, a somewhat prolonged prothrombin time and/or an increase in bromsulphalein retention. In considering these findings, the excessive consumption of alcohol mentioned above should be taken into account.

«Thanks are due to Elisabeth Tibblin, M.D., for her interpretation of the sternal punctures.

TABLE I

SYMPTOMS AND SOME OF THE MORE IMPORTANT LABORATORY DATA

\begin{tabular}{|c|c|c|c|c|c|c|c|c|c|}
\hline Patient & Age & Symptoms & $\begin{array}{l}\text { Duration } \\
\text { of } \\
\text { Symptoms } \\
\text { (mths) }\end{array}$ & $\begin{array}{l}\text { Lead } \\
(\mu g . / \mathrm{I} \\
\text { Blood }\end{array}$ & $\frac{\text { ml.) }}{\text { Urine }}$ & $\begin{array}{l}\text { ALA } \\
(m g . / 100 \\
\text { ml. urine })\end{array}$ & $\begin{array}{l}\text { Copropor- } \\
\text { phyrins } \\
\text { ( } \mu g . / 100 \\
\text { ml. urine) }\end{array}$ & $\begin{array}{l}\mathrm{Hb} \\
(g \cdot / 100 \\
m l .)\end{array}$ & $\begin{array}{l}\text { Punctate } \\
\text { Basophils } \\
\text { (per 10,000 } \\
\text { R.B.C.) }\end{array}$ \\
\hline I & 34 & $\begin{array}{l}\text { Fatigue, metal-taste, loss of weight, } \\
\text { constipation }\end{array}$ & $1 \cdot 5$ & 85 & 19 & $5 \cdot 80$ & $12 \cdot 3$ & 10.8 & 36 \\
\hline II & 48 & $\begin{array}{l}\text { Fatigue, metal-taste, loss of appetite } \\
\text { and weight, epigastric pain, myalgia }\end{array}$ & $I \cdot 5$ & IIO & 68 & $5 \cdot 20$ & $77 \cdot 0$ & 12.0 & 25 \\
\hline III & 26 & $\begin{array}{l}\text { Fatigue, metal-taste, loss of appetite, } \\
\text { nausea, vomiting, diarrhoea, loss of } \\
\text { weight, muscle cramps, loss of ten- } \\
\text { don reflexes }\end{array}$ & $1 \cdot 5$ & 130 & $6 I$ & $6 \cdot 60$ & - & I I $\cdot 9$ & 21 \\
\hline IV & 26 & $\begin{array}{l}\text { Fatigue, irritability, headache, ab- } \\
\text { dominal colic, muscle cramps }\end{array}$ & $2 \cdot 0$ & 100 & 22 & $5 \cdot 60$ & $8 I \cdot 0$ & 10.6 & 27 \\
\hline V & $4 I$ & $\begin{array}{l}\text { Fatigue, irritability, metal-taste, } \\
\text { nausea, constipation alternating with } \\
\text { diarrhoea, loss of weight }\end{array}$ & $I \cdot 0$ & 85 & 23 & $4 \cdot 40$ & - & II $\cdot 7$ & 73 \\
\hline VI & 24 & $\begin{array}{l}\text { Fatigue, headache, loss of appetite, } \\
\text { nausea, vomiting, epigastric pain, } \\
\text { diarrhoea, loss of weight }\end{array}$ & 2.5 & 95 & 40 & $5 \cdot 35$ & $43 \cdot 7$ & $13 \cdot 0$ & 17 \\
\hline VII & 39 & $\begin{array}{l}\text { Fatigue, diarrhoea, muscle cramps, } \\
\text { paresthesiae }\end{array}$ & $2 \cdot 0$ & 45 & I6 & $I \cdot 90$ & $25 \cdot 2$ & 13.4 & 21 \\
\hline VIII & 48 & $\begin{array}{l}\text { Fatigue, irritability, headache, metal- } \\
\text { taste, loss of appetite, muscle cramps }\end{array}$ & $2 \cdot 5$ & 75 & 33 & $3 \cdot 20$ & $70 \cdot 2$ & $13 \cdot 1$ & 9 \\
\hline IX & 34 & $\begin{array}{l}\text { Fatigue, irritability, metal-taste, loss } \\
\text { of appetite, nausea, loss of weight, } \\
\text { abdominal colic, constipation alter- } \\
\text { nating with diarrhoea, muscle cramps }\end{array}$ & $1 \cdot 5$ & 80 & 6 & $2 \cdot 60$ & - & I I $\cdot \mathbf{I}$ & IO \\
\hline $\mathrm{x}$ & 49 & No symptoms & 一 & 75 & II & $I \cdot 30$ & $3 \cdot 0$ & $12 \cdot 2$ & 37 \\
\hline XI & 25 & $\begin{array}{l}\text { Fatigue, headache, nausea, vomit- } \\
\text { ing, abdominal colic }\end{array}$ & $1 \cdot 5$ & 65 & 12 & $I \cdot 70$ & $36 \cdot 2$ & $9 \cdot 8$ & $\mathbf{I}$ \\
\hline XII & 40 & Nausea & $1 \cdot 0$ & 60 & 32 & $I \cdot 30$ & $29 \cdot 0$ & $13 \cdot 2$ & 5 \\
\hline XIII & 46 & Fatigue, metal-taste & $I \cdot 0$ & 50 & 7 & 0.36 & $5 \cdot 6$ & II $\cdot \mathbf{I}$ & 3 \\
\hline XIV & 39 & Fatigue & $2 \cdot 0$ & 50 & I I & $0 \cdot 73$ & $8 \cdot 2$ & 10.8 & 6 \\
\hline XV & 57 & $\begin{array}{l}\text { Fatigue, headache, loss of appetite, } \\
\text { loss of weight }\end{array}$ & $2 \cdot 0$ & 40 & 10 & 0.65 & $16 \cdot 2$ & I I $\cdot 7$ & 3 \\
\hline
\end{tabular}




\section{Methods}

Laboratory Methods Delta-aminolaevulic acid (ALA), coproporphyrins (CP), lead, and creatinine in urine were determined by the same methods as those described in our previous paper in this Journal (Cramér and Selander, 1965). Lead in whole blood was determined by the spectrographic method of Danielsson (1952). Standard methods were used for all other analyses.

Normal values for urinary ALA, lead, and CP given by Haeger-Aronsen (1960) are: ALA $0.29 \mathrm{mg}$./100 ml. urine, S.D. $=0.14$; lead I. $4 \mu \mathrm{g} . / 100 \mathrm{ml}$. urine, S.D. $=$ 0.9; CP $7 \mu \mathrm{g}$. $/ 100 \mathrm{ml}$. urine, S.D. $=4$.

Contrary to former opinions (Folin, 1905; Marshall, 1920; Hunter, 1922) there is circumstantial evidence of considerable variations in the urinary output of creatinine in the individual (Bleiler and Schedl, 1962; Doolan, Alpen and Theil, 1962; Paget, Liefooghe, Duhamel and Parent, 1962). We have been able to confirm these observations and, further, we have found that the variations are of the same size as those of the urinary volume (Cramér, Cramér, and Selander, to be published). Thus, we have chosen to express all values from urinary analyses in amount per $100 \mathrm{ml}$. urine instead of relating them to the creatinine output.

For whole blood lead Kehoe, Cholak, and Story (1940 $\mathrm{a}, \mathrm{b})$ found a normal value of $25 \pm 10 \mu \mathrm{g}$./100 ml. and Goldberg et al. (1963) $22.9 \mu \mathrm{g} . / 100 \mathrm{ml} .$, S.D. $=8 \cdot 2$. Both groups applied a dithizone method. For the present spectrographic method, Holmquist (1965) gives a normal value of $20 \pm 10 \mu \mathrm{g}$./100 ml. for an urbanized Swedish population.

Plan of Study All patients were in hospital during treatment. The patients were supervised carefully and instructed to collect their urine quantitatively. Initial laboratory studies were made during the first 24 hours after admission. Then the outputs of lead, ALA, and creatinine were determined in every 24-hour sample of urine.

Before, and the day after, completion of the therapy, and once a week during the therapy, the following tests were performed: haemoglobin concentration, red and white cell counts, differential count, thrombocyte count, reticulocyte count, basophilic stippled erythrocyte count, serum iron concentration, haptoglobin in serum, serum bilirubin, thymol turbidity, serum alkaline phosphatases, prothrombin time, proaccelerin-proconvertine-test, serum glutamic oxaloacetic and pyruvic transaminases, serum electrophoresis, determination of serum electrolytes including serum calcium, serum creatinine, determination of whole blood lead, examination for urinary protein, and examination of the urinary sediment.

Treatment D-penicillamine capsules were given in doses varying between 750 and 1,500 mg. per day, divided into three doses. The total dose and the duration of the therapy for each patient are shown in Table II.

In order to establish a suitable dosage of penicillamine, various dosage schedules were used.

In two subjects, the effect of intermittent therapy was compared with that of continuous therapy. Periods of continuous treatment with $750 \mathrm{mg}$. daily given for four days were alternated with periods of intermittent therapy with I,500 mg. every second day (Fig. 3). Thus, the same amount of PCA was given during each four-day period. Continuous treatment was started in one patient and intermittent treatment in the other. The output of lead during each period was compared with the total output during treatment.

Two other subjects received varying doses in four-day periods. Thus, periods of $750 \mathrm{mg}$. daily were alternated with periods of $\mathrm{I}, 500 \mathrm{mg}$. daily (Fig. 4). Then the excretions of lead during the periods were compared.

Intermittent therapy was given to three other subjects, but the dosage schedules were not comparable.

TABLE II

Effect of Therapy on Lead Excretion, Concentration of Lead in Blood aNd URine, and on Concentration of Ala In URINE

\begin{tabular}{|c|c|c|c|c|c|c|c|c|c|c|}
\hline \multirow[t]{2}{*}{ Patient } & \multirow{2}{*}{$\begin{array}{l}\text { Total } \\
\text { Dosage } \\
P C A(g .)\end{array}$} & \multirow{2}{*}{$\begin{array}{l}\text { Duration } \\
\text { (days) }\end{array}$} & \multicolumn{2}{|c|}{ Excretion of Lead (mg.) } & \multirow{2}{*}{\multicolumn{2}{|c|}{$\begin{array}{l}\text { Lead in Blood before } \\
\text { and after Therapy } \\
(\mu \mathrm{g} / \mathrm{/} 00 \mathrm{ml} .)\end{array}$}} & \multirow{2}{*}{\multicolumn{2}{|c|}{$\begin{array}{l}\text { Lead in Urine } \\
\text { before and after } \\
\text { Therapy } \\
(\mu \mathrm{g} . / 100 \mathrm{ml} .)\end{array}$}} & \multirow{2}{*}{\multicolumn{2}{|c|}{$\begin{array}{l}\text { ALA in Urine before } \\
\text { and after Therapy } \\
(\mathrm{mg} . / 100 \mathrm{ml} .)\end{array}$}} \\
\hline & & & \multirow{2}{*}{$\begin{array}{l}\text { Total } \\
3 \mathbf{1} \cdot \mathbf{2}\end{array}$} & \multirow{2}{*}{$\begin{array}{l}\text { Ifirst } 9 \mathrm{~g} ._{P C A} \\
19.5\end{array}$} & & & & & & \\
\hline I & $22 \cdot 5$ & 25 & & & 85 & 40 & 19 & 20 & 5.80 & 0.35 \\
\hline II & $30 \cdot 0$ & 28 & $29 \cdot 5$ & $17 \cdot 1$ & 110 & 40 & 68 & 10 & $5 \cdot 20$ & 0.30 \\
\hline III & 16.5 & 22 & $28 \cdot 0$ & 20.5 & 130 & 30 & 61 & 8 & 6.60 & 0.40 \\
\hline IV & $22 \cdot 5$ & 25 & $24 \cdot 1$ & $14 \cdot 2$ & 100 & 30 & 22 & 7 & $5 \cdot 60$ & 0.22 \\
\hline V & 33.75 & 29 & $27 \cdot 4$ & $13 \cdot 1$ & 85 & 25 & 23 & 17 & 4.40 & 0.52 \\
\hline VI & $18 \cdot 0$ & 20 & $20 \cdot 6$ & 13.5 & 95 & 35 & 40 & II & $5 \cdot 35$ & 0.27 \\
\hline VII & 13.5 & 19 & II 99 & $7 \cdot 3$ & 45 & 40 & 16 & 8 & $1 \cdot 90$ & 0.30 \\
\hline VIII & $16 \cdot 2$ & 18 & 10.5 & $7 \cdot 4$ & 75 & 40 & 33 & II & $3 \cdot 20$ & 0.37 \\
\hline IX & $33 \cdot 0$ & 22 & $27 \cdot 4$ & 13.3 & 80 & 20 & 6 & 6 & $2 \cdot 60$ & 0.30 \\
\hline $\mathbf{x}$ & $25 \cdot 5$ & I 7 & $15 \cdot 3$ & 6.7 & 75 & 50 & I I & 6 & $\mathbf{I} \cdot 30$ & 0.30 \\
\hline $\mathbf{X I}$ & $24 \cdot 0$ & 20 & II $\cdot 8$ & $6 \cdot 6$ & 65 & 20 & 12 & I I & $\mathbf{I} \cdot 70$ & 0.37 \\
\hline XII & 18.9 & 21 & 13.2 & $8 \cdot 2$ & 60 & 40 & 32 & 10 & $1 \cdot 30$ & 0.27 \\
\hline XIII & $15 \cdot 0$ & 16 & 6.5 & $4 \cdot 3$ & 50 & 20 & 7 & 5 & 0.36 & 0.36 \\
\hline XIV & $9 \cdot 75$ & 13 & $3 \cdot 6$ & $3 \cdot 4$ & 50 & 25 & I I & 5 & 0.73 & 0.24 \\
\hline XV & 9.0 & 13 & $3 \cdot 0$ & $2 \cdot 8$ & 40 & 35 & 10 & - & 0.65 & 0.23 \\
\hline
\end{tabular}


The remaining eight subjects were given continuous therapy.

\section{Results}

Results of Treatment with PCA Rapid clinical improvement was obtained in all subjects. Symptoms of lead poisoning disappeared within one week of starting treatment in all patients except patient III whose loss of tendon reflexes persisted after the therapy. An average weight gain of 2.25 kg. was noted in 12 patients. The weight was not registered in the other three subjects.

Increased stippled cell counts became normal in all patients. The granulocyte count returned to normal values in four of the five patients with granulocytopenia.

The haemoglobin values did not show any considerable rise in most of the patients. Thus, in 12 patients there was an average increase of $0.7 \mathrm{~g} . / 100$ $\mathrm{ml}$. The greatest increase observed was $2.9 \mathrm{~g}$./100 ml. in patient XIV.

In all patients with pathological laboratory results indicating liver damage, the values returned to normal during treatment.

The effects of the therapy on the lead concentration in blood and in urine and on urinary ALA concentration are shown in Table II. The total output of lead during the therapy and the output after a dose of $9 \mathrm{~g}$. PCA were determined.

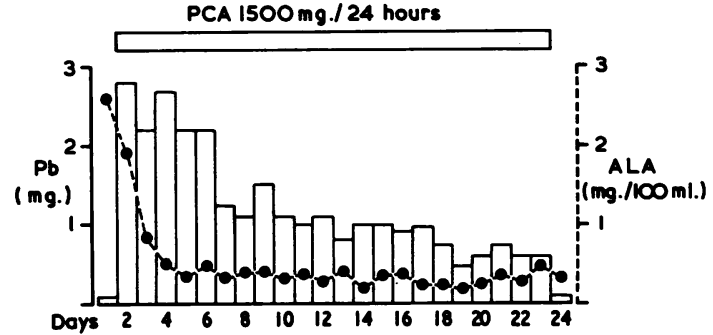

FIG. I. Patient IX. Effect of therapy on daily excretion and concentration of ALA in urine.

The urinary output of lead showed an immediate increase at the beginning of the therapy and followed a distinct pattern during continued therapy. During an initial period of five to seven days, the daily urinary output of lead was fairly constant. The output then diminished continuously during prolonged therapy and decreased to values below $0.5 \mathrm{mg}$./day. As would be expected, more prolonged treatment was necessary in patients with particularly severe poisoning.

The urinary output of ALA decreased markedly and rapidly to a normal value during PCA therapy. Thus, there were normal urinary ALA values in spite of an increased urinary output of lead. This is well demonstrated in patient IX (Fig. I), who had a normal ALA value $(0.5 \mathrm{mg}$./100 ml.) on the third

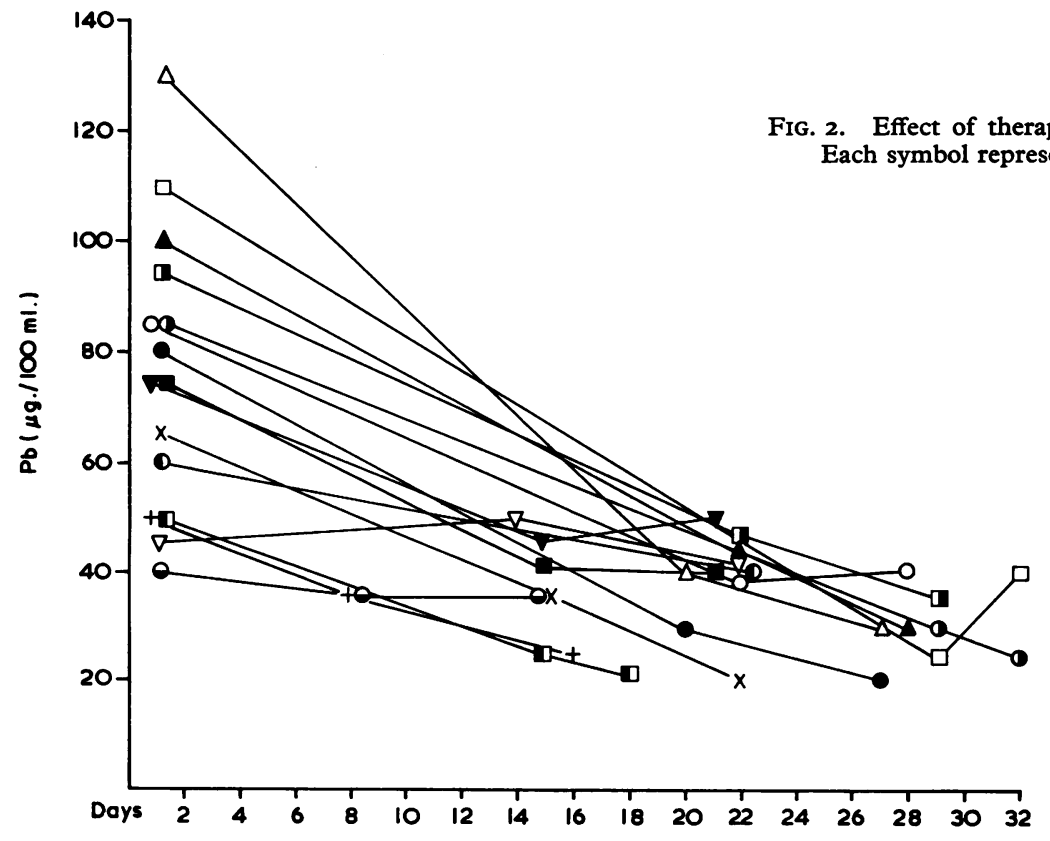


day of treatment. During the remaining 20 days, an output of $19.75 \mathrm{mg}$. of lead was obtained, i.e., $72 \%$ of the total urinary output of lead. lead in blood during treatment. The values are those on the day before and the day after treatment and from the last week of treatment. Intermediate values obtained from samples during the therapy are omitted from the figure. The concentration of lead in blood decreased continuously during treatment except in one result from a sample in patient VII.

The results of the comparison between intermittent and continuous therapy are shown in Figure 3. In the first patient, we started with continuous treatment and in the other with intermittent. The total amount of PCA administered during each fourday period was the same. A comparison between the two patients showed that, during each period with continuous therapy, a greater part of the total lead output was excreted than during the corresponding period of intermittent therapy. The figure also shows that PCA had no delayed effect on the lead excretion. Thus, the day after PCA was withdrawn the output of lead decreased to values below or equal to the initial output before therapy.

The results of continuous therapy with various dosages are given in Fig. 4, which shows the lead

FIG. 3. Effect of continuous therapy compared with intermittent therapy. For each four-day period, the total dosage of PCA is the same. One therapy-free day is inserted after the last day of therapy in each period to avoid influence from one period to the next. Each period's part of the total lead excretion is determined.
Figure 2 shows the changes in concentration of
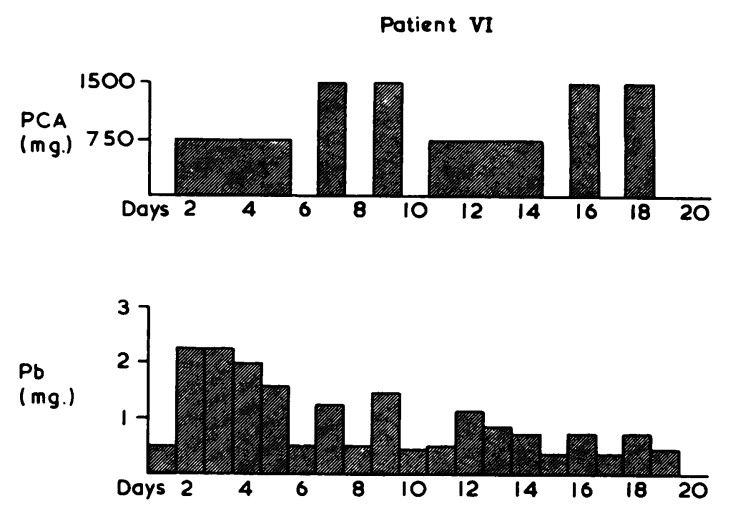

Percent. totol
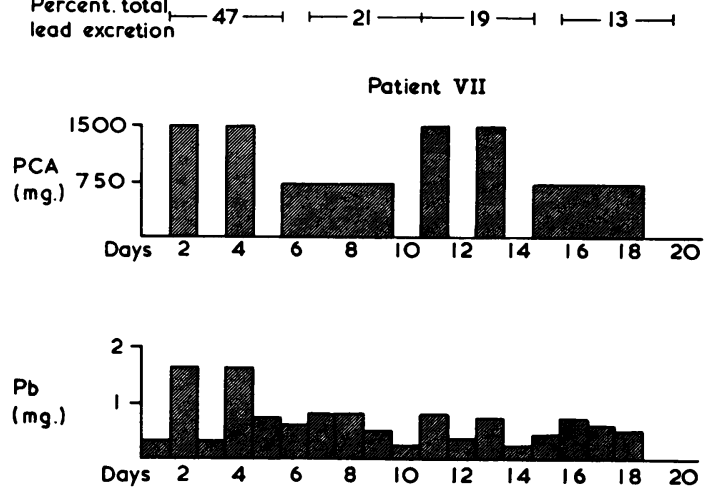

Percent. totol lead excretion
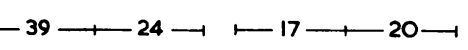

Potlent II

Potient V
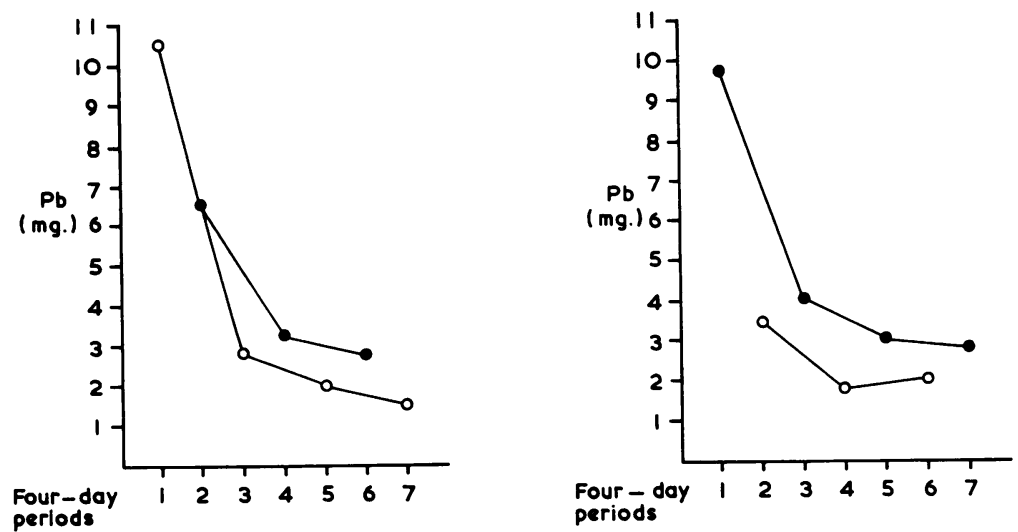

FIG. 4. Effect of therapy with various doses in alternating four-day periods. Each marking represents the lead excretion during one four day period. 
output in two patients who received $750 \mathrm{mg}$. or I,500 mg. PCA daily in alternating periods of four days. In the first patient, treatment was started with I,500 mg. daily, and in the other with $750 \mathrm{mg}$. daily. Each marking in the figure represents the amount of lead excreted during a four-day period. In both patients, a continuous decrease in urinary lead output was obtained during the therapy, but, throughout, the effect of the higher dosage was better than that of the lower one.

Correlation between Lead in Blood and Some Other Laboratory Data Correlation coefficients between initial values for lead in blood, lead in urine, ALA, coproporphyrins in urine, and the output of lead during therapy with $9 \mathrm{~g}$. PCA are given in Table III. We consider the lead output

TABLE III

CORRELATION COEFFICIENTS BETWEEN INITIAL VALUES FOR LEAD IN BLOOD, CONCENTRATIONS IN URINE OF LEAD, ALA AND CP, AND OUTPUT OF LEAD DURING THERAPY WITH $9 \mathrm{~g}$. PCA

\begin{tabular}{llrrl}
$A$ & $B$ & $n$ & $r A B$ & $P$ \\
\hline Lead in blood & ALA in urine & 15 & 0.90 & $<0.001$ \\
Lead in blood & Lead in urine & 15 & 0.76 & $<0.01$ \\
Lead in blood & CP in urine & 12 & -0.57 & N.S. \\
Lead in blood & Lead excreted & & 0.89 & $<0.001$
\end{tabular}

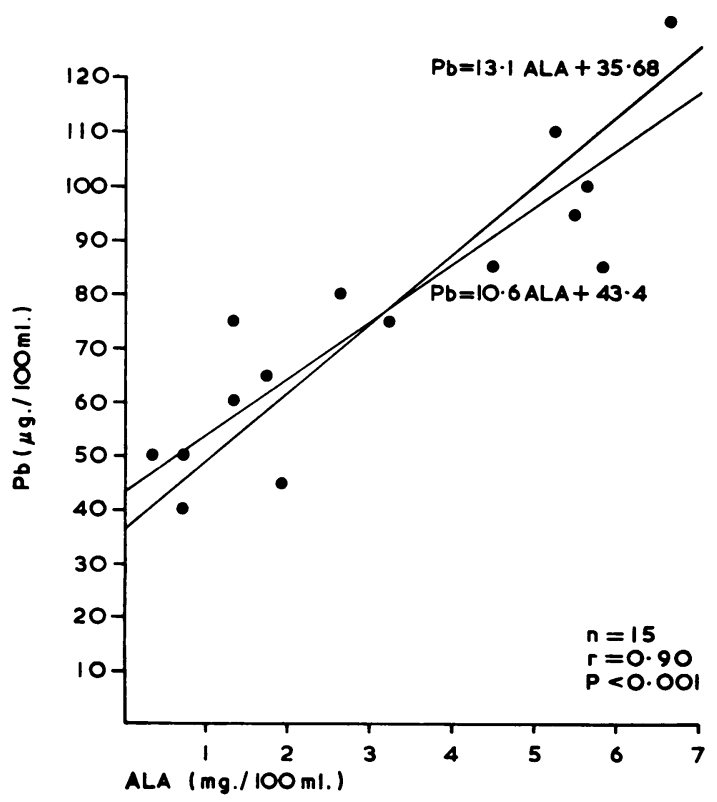

Frg. 5. Correlation between initial values for lead in blood and ALA in urine.

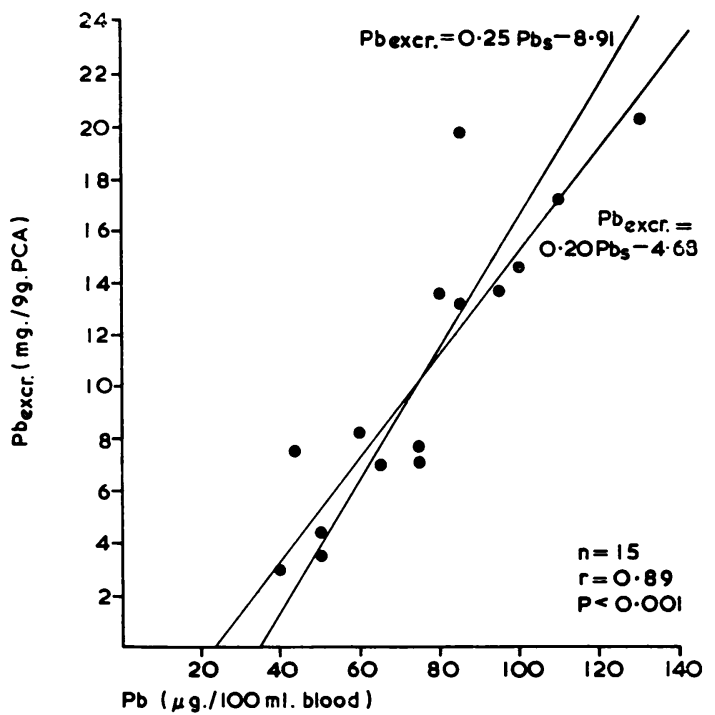

FIG. 6. Correlation between initial values for lead in blood (Pbs) and amount of lead excreted during therapy with 9 g. PCA.

during therapy to be a good measure of the degree of lead poisoning if there has been an interval of one week or more between the last exposure and the therapy (Cramér and Selander, 1965). Because the patients were treated with different total dosages, we have, for the correlations, chosen the excretion during therapy with $9 \mathrm{~g}$. PCA, which was the smallest total dose given. We found an almost linear, positive correlation between lead in blood and ALA and between lead in blood and lead output during therapy with 9 g. PCA (Figs. 5 and 6). There is no significant difference between the regression lines in the two figures. A positive correlation was found also between lead in blood and lead in urine, whereas the correlation between lead in blood and coproporphyrins was negative and not statistically significant.

The correlation between lead in blood and ALA also persisted during the therapy as shown in Fig. 7 where the values before, after, and in the middle of therapy are given. The slopes of the regression lines are in the same range as the slopes given in Figure 5.

Side Effects The frequency of side effects is shown in Table IV. This Table also includes values for serum iron before and after therapy. In patients IV, VIII, IX, and XI, a sternal puncture was performed after therapy. The puncture revealed an almost complete absence of reticular iron.

Exanthemata appeared in four patients after seven to Io days of therapy and were accompanied by 


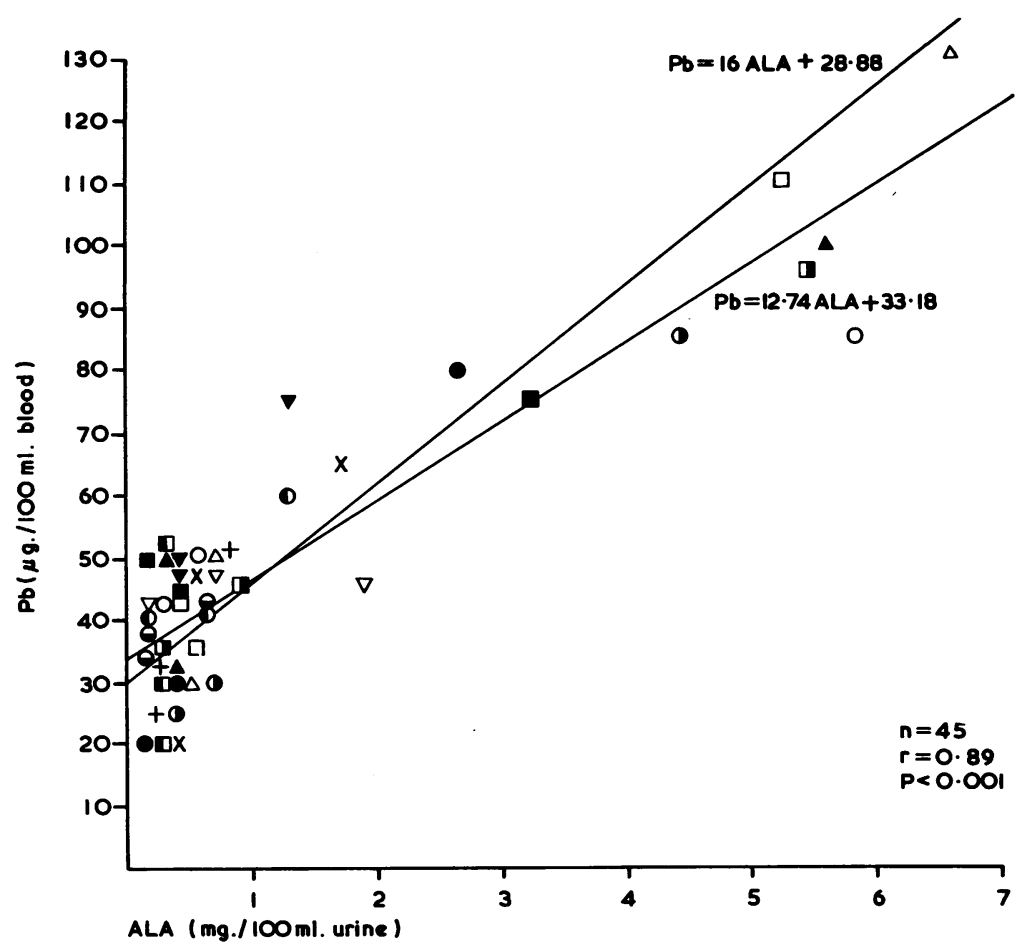

FIG. 7. Correlation between levels of lead in blood and ALA in urine during the course of therapy. Each symbol represents one patient. Three values are given for every patient: on the day before therapy, after therapy, and in the middle of therapy.

TABLE IV

VALUES FOR SERUM IRON BEFORE AND AFTER THERAPY: FREQUENCY OF SIDE EFFECTS

\begin{tabular}{|c|c|c|c|c|c|c|}
\hline Patient & $\begin{array}{l}\text { Seru } \\
\text { befor } \\
\text { after } \\
\text { Ther } \\
\text { ( } \mu g .)\end{array}$ & $\begin{array}{l}n \text { Iron } \\
\text { and } \\
\text { apy } \\
\text { I00 } m l .)\end{array}$ & Exanthem & Fever & $\begin{array}{l}\text { Eosino- } \\
\text { philia } \\
>4 \%\end{array}$ & $\begin{array}{l}\text { Granulo- } \\
\text { cytopenia } \\
<2000 / \mathrm{mm}^{3}\end{array}$ \\
\hline I & 180 & 50 & & & + & \\
\hline II & 220 & 120 & & & & $(+)$ \\
\hline III & 190 & 35 & + & & + & $\begin{array}{l}\text { Agranulo- } \\
\text { cytosis }\end{array}$ \\
\hline $\begin{array}{l}\text { IV } \\
\text { V }\end{array}$ & $\begin{array}{l}120 \\
290\end{array}$ & $\begin{array}{r}60 \\
180\end{array}$ & & & + & \\
\hline $\begin{array}{r}\text { VI } \\
\text { VII }\end{array}$ & $\begin{array}{r}228 \\
65\end{array}$ & $\begin{array}{r}85 \\
110\end{array}$ & + & + & + & $(+)$ \\
\hline VIII & $\begin{array}{l}165 \\
160\end{array}$ & $\begin{array}{r}55 \\
120\end{array}$ & + & & + & + \\
\hline$\underset{\mathrm{XI}}{\mathrm{X}}$ & $\begin{array}{r}175 \\
95\end{array}$ & $\begin{array}{l}90 \\
40\end{array}$ & & & $\begin{array}{l}+ \\
+\end{array}$ & \\
\hline XII & 190 & 130 & & & + & \\
\hline XIII & 100 & 60 & + & + & + & \\
\hline$\underset{\text { XV }}{\text { XIV }}$ & $\begin{array}{r}235 \\
75\end{array}$ & $\begin{array}{r}135 \\
85\end{array}$ & & & & \\
\hline
\end{tabular}

itching. Two of the patients had a slight fever. The response to treatment with antihistamine was very good and it was not necessary to stop the PCA therapy.

Eosinophilia was rather frequent but was associated with other signs in only three patients. In these, the fever and exanthemata disappeared during treatment with antihistamines, but the eosinophilia was not affected. The highest value observed was $18.5 \%$.

In patient III, a complete agranulocytosis occurred after 20 days therapy with PCA. The white blood count fell to $1,800 / \mathrm{mm}^{3}$ with a differential count of $97 \%$ lymphocytes and 3\% monocytes. A small dose of antazoline had also been given because of a rash. This case has been published separately (Selander and Cramér, 1965). Patient VIII developed a slight granulocytopenia. In the course of 14 days, the granulocytes were reduced from 2,700 to $1,000 / \mathrm{mm}^{3}$. In patients II and VI, low granulocyte counts were found on admission, but there was a slight decrease during therapy (from 
I,650 to $\mathrm{I}, 350$ per $\mathrm{mm}^{3}$ and from 975 to 800 per mm. ${ }^{3}$ respectively). No further symptoms or signs of side effects were observed during therapy. There was no relationship between side effects and PCA dosage.

\section{Discussion}

General Remarks on PCA Therapy The therapeutic effect of PCA on clinical symptoms and pathological laboratory tests was evident in all patients. It was somewhat surprising, however, that the haemoglobin did not show the same rapid return to normal as other laboratory tests, even though the observation time was relatively short. The same observation was reported by Goldberg et al., 1963. This may possibly be due to the effect on serum iron levels, which dropped in all patients, and the corresponding disappearance of reticular iron in the bonemarrow. In the three patients with the greatest increase in haemoglobin, the serum iron levels were initially high and did not drop to pathological levels during treatment. In seven patients, the serum iron level was determined Io days to three weeks after therapy. The low values persisted except in one patient. Administration of iron is recommended after treatment with penicillamine. This may apply also to other metals which have not been studied in this series.

The presence of granulocytopenia in five patients when admitted to hospital is remarkable, since no other report of this condition in lead poisoning seems to be available. A careful survey of all other agents which may possibly give rise to granulocytopenia (drugs, organic solvents, or the like) did not explain the phenomenon. It should be noted, however, that 13 of the 15 patients were employed in shipbreaking yards cutting painted iron with welding flames, and that smoke products and combustion emanating from the paint could have influenced the myelopoiesis. Another possible explanation of the granulocytopenia is an excessive consumption of alcohol (Libre, I964), but it must be stressed that there was no relationship between the presence of granulocytopenia and the pathological laboratory results indicating liver damage.

It is not justified, however, to conclude that the normalization of granulocytopenia in four out of five patients and of laboratory tests on liver function in all patients was due to the PCA therapy. The normalization of the values can also be explained by the fact that the patients were withdrawn from alcohol or other noxious agents by hospitalization. It is evident, however, that PCA therapy was not shown to have any harmful influence on the liver functions.
The side effects of PCA were generally mild and could easily be managed by treatment with antihistamines. One patient with agranulocytosis responded rapidly to standard therapy. As the provocation tests were entirely negative, we find it more reasonable to assume that the agranulocytosis was caused by a toxic influence rather than by an immunological mechanism. Two similar cases, both following prolonged therapy with PCA for Wilson's disease with a dosage of $2 \mathrm{~g}$. daily, have been reported (Corcos, Soler-Bechara, Mayer, Freyberg, Goldstein, and Jaffe, 1964). Until additional experience has been gained, regular white cell and differential counts should be made during PCA therapy. The frequent occurrence of eosinophilia during therapy should be considered.

The normalization of values for lead in blood and for ALA in urine occurred simultaneously (Fig. 7). Neither of these parameters, however, should be used to judge whether or not the therapy should be discontinued. As shown in Fig. I, considerable amounts of lead could be excreted after a complete normalization of the values for ALA in urine. The same observation is reported in one patient by Goldberg et al. (1963). As the urinary output of ALA appears to be a direct measure of metabolically active lead in the organism (Haeger-Aronsen, 1960; Cramér and Selander, 1965), it is postulated that PCA administration chelates this lead into an inactive form which is then gradually excreted. Treatment should therefore be continued until a low and steady urinary lead output has been obtained. Depending on the degree of lead poisoning, this means that treatment should last for between 15 and 30 days.

The concentration of lead in urine is consequently important when controlling the therapy. On the other hand, it is not to be relied on as a measure of the degree of lead poisoning (Cramér and Selander, 1965). Table II shows that, in several patients, the concentration of lead in urine was almost the same before and after the therapy and that it did not follow the same pattern as the lead values in blood and the concentration of ALA in urine. Thus, the urinary concentration of lead is not directly dependent on the concentration of lead in the blood. With high blood levels, it is possible that a great deal of the lead is excreted in organic forms and reabsorbed in the renal tubules (Vostal, 1965).

It is sometimes suggested that intermittent therapy of lead poisoning is better than continuous therapy, because during the 'rest' days more lead would become available for the chelating agent. In our patients, however, the comparison between intermittent and continuous therapy did not confirm 
such a theory, neither was there any delayed effect of PCA during the day after it was given. We therefore recommend continuous therapy, and, as there was no relationship between the frequency of side effects and the dose, I,500 $\mathrm{mg}$. daily is suggested. In passing, we may mention that more recently we have given $2,000 \mathrm{mg}$. daily to several patients without any serious side effects.

Our conclusion is that PCA is a good alternative to Ca-EDTA in the treatment of lead poisoning. It is possible that $\mathrm{Ca}-\mathrm{EDTA}$ is preferable in severe cases, but the great advantage of PCA is its effectiveness when given orally, and that, among other things, it is not necessary to admit the patient to hospital. Furthermore, it is often not even necessary to take him away from work. Instead, the patient can be transferred temporarily to a job without lead exposure.

The side effects do not seem to be as serious as those from Ca-EDTA. For control during the therapy the most important factor is the white cell count which can be done, for example, by an industrial nurse. These advantages also result in an important economic gain for all involved-the patient, the employer, and society.

Lead in Blood-Relationship to ALA in Urine and Mobilizable Lead In a previous paper we compared the value of different laboratory tests when evaluating the degree of lead poisoning as reflected by the excreted amount of lead during therapy with a common dosage of $9 \mathrm{~g}$. PCA. A very strong correlation was found between this amount of lead and the initial values for urinary ALA ( $r=0.92 ; P<0.001)$, while the correlations between lead excreted during therapy and initial values for urinary lead and coproporphyrins were much weaker.

In the present paper, these observations have been extended to include the initial values for lead in blood. There was a very strong correlation between lead in blood and lead excreted during therapy with 9 g. PCA (Fig. 6), as good as that found for urinary ALA.

The correlation between lead in blood and ALA was also very strong (Fig. 5). It would be erroneous, however, to conclude that determinations of lead in blood and ALA in urine express the degree of lead poisoning equally well. Values for ALA ought to be an expression of a metabolic action of lead, while the lead level in blood might be very high because of an acute exposure (Holmquist, I965).

In the present series, however, there is an interval of one to five weeks between the last exposure and the laboratory investigations. In these circumstances it appears that lead in blood and urinary ALA are equivalent as expression for the degree of lead poisoning. The collection of specimens for determination of ALA, however, does not require the same precautions as the collection of blood samples for lead determinations, and the costs for the laboratory work are less than half those for lead determinations.

The interrelationship between lead in blood and ALA in urine is retained during the whole course of treatment (Fig. 7).

Where to set an acceptable upper limit for lead in blood, above which the workers are kept away from further exposure, is a matter of dispute. Usually, values between 60 and $80 \mu \mathrm{g} . / 100 \mathrm{ml}$. blood are given (Brugsch, 1948; Fleming, 1964; Holmquist, 1962; Kehoe, 1949; Portheine, 1952). We think that the question depends very much on the attitude to the problem of prevention. From the regression lines in Fig. 7 it is possible to calculate that a lead level of $60 \mu \mathrm{g}$./100 ml. blood corresponds to an ALA-value in urine of $2 \mathrm{mg}$./100 ml., and $80 \mu \mathrm{g}$./100 $\mathrm{ml}$. corresponds to 3.5 to $4 \mathrm{mg}$. $/ 100 \mathrm{ml}$.

Further studies are probably necessary to set such limit values for ALA in urine, but we think that they ought to be in the range of 2 to $2.5 \mathrm{mg}$. $/ 100 \mathrm{ml}$. It must be emphasized that a raised ALA value always means the presence of metabolically active lead.

As seen in Fig. 6, it is possible from the level of lead in blood to calculate the amount of lead which can be excreted during therapy with $9 \mathrm{~g}$. PCA with a high degree of accuracy. It should be kept in mind, however, that similar calculations probably may not be valid if based on the levels of lead in blood following an acute exposure.

We are very grateful to Miss Birgitta Börjesson for her skilful laboratory aid.

\section{REFERENCES}

Bleiler, R. E., and Schedl, H. P. (1962). F. Lab. clin. Med., 59, 945 .

Boulding, J. E., and Baker, R. A. (1957). Lancet, 2, 985.

Brugsch, T. (1948). Lehrbuch der inneren Medizin, 13th ed., Vol. 2. Berlin.

Corcos, J. M., Soler-Bechara, J., Mayer, K., Freyberg, R. H., Goldstein, R., and Jaffe, I. (1964). . Amer. med. Ass., 189, 265.

Cramér, K., and Selander, S. (1965). Brit. F. industr. Med., 22, 311.

Dagg, J. H., Goldberg, A., Lochhead, A. C., and Smith, J. A. (1965). Quart. F. Med., n.s. 34, I63.

Danielsson, A. (1952). Schr. Ges. Dtsch. Metallhütten-und Bergleute, Heft 3, p. 97.

Doolan, P. D., Alpen, E. L., and Theil, G. B. (1962). Amer. F. Med., 32, 65.

Fleming, A. J. (1964). Arch. environm. Hlth, 8, 266. 
Folin, O. (1905). Amer. F. Physiol., 13, 66.

Foreman, H. (1960). In Metal-Binding in Medicine, Proc. Symp. Hahnemann Medical College, Philadelphia, ed. M. J. Seven, pp. 83-94. Lippincott, Philadelphia.

—, Finnegan, C., and Lushbaugh, C. C. (1956). F. Amer. med. Ass., 160, 1042.

Goldberg, A., Smith, J. A., and Lochhead, A. C. (1963). Brit. med. F., I, 1270.

Haeger-Aronsen, B. (1960). Scand. F. clin. Lab. Invest., 12, Suppl. 47.

Harris, C. E. C. (1958). Canad. med. Ass. F., 79, 664.

Holmquist, I. (1962). Nord. med., 67, 46.

- (1965). Report from the Ronnskar Smelting Works, Skelleftehamn, Sweden.

Hunter, A. (1922). Physiol. Rev., 2, 586.

Johnstone, R. T. (1964). Arch. environm. Hlth, 8, 250.

Kehoe, R. A. (1949). In Industrial Hygiene and Toxicology, ed. F. A. Patty, Vol. 2, pp. 643-673. Interscience Publ., New York.

- Cholak, J., and Story, R. V. (I940a). f. Nutr., 19, 579. - -, (1940b). Ibid., 20, 85 .

Libre, E. (1964). Personal communication.
Marshall, E. K., Jr. (1920). F. Pharmacol. exp. Ther., 16, 141. Moeschlin, S. (1957). Schweiz. med. Wschr., 87, I091.

Moncrieff, A. A., Koumides, O. P., Clayton, B. E., Patrick, A. D., Renwick, A. G. C., and Roberts, G. E. (1964). Arch. Dis. Childh., 39, I.

Ohlsson, W. T. L. (1962). Brit. med. F., I, 1454.

Paget, M., Liefooghe, J., Duhamel, M., and Parent, G. (1962). Ann. Biol. clin., 20, 757.

Perol, R., Graveleau, J., Potter, M., and Morin, M. (1962). Sem. Hôp. Paris., 38, 3342.

Portheine, F. (1952). Klin. W schr., 30, 83.

Rieders, F., and Brieger, H. (1955). Proceedings of the Seventh Annual Meeting of the American Academy of Occupational Medicine, pp. 83-84.

Selander, S., and Cramér, K. (1965). Brit. med. F., 2, 171.

Shiels, D. O., Thomas, D. L. G., and Kearley, E. (1956). Arch. industr. Hlth, 13, 489.

Vogt, W., and Cottier, H. (1957). Schweiz. med. Wschr., 87, 665.

Vostal, J. (1965). Personal communication.

Walshe, J. M. (1956). Amer. F. Med., 21, 487.

Zavon, M. R. (1964). Arch. environm. Hlth, 8, 262. 